\title{
Implementasi Pendidikan Nilai Nasionalisme dalam Pembelajaran Living Values
}

\author{
An-Nisa Apriani, \\ Prodi PGSD Universitas Alma Ata Yogyakarta \\ Email: akunnisa@gmail.com \\ Yusinta Dwi Ariyani \\ Prodi PGSD Universitas Alma Ata Yogyakarta
}

\begin{abstract}
This research aims to investigate the implementation of educational values of nasionalism in the living values learning process on the preparation class at SD Tumbuh 1 Yogyakarta. The data were collected by qualitative-descriptive method. Participants of this research included the principal, the teachers, and the students. The object of this research is the process of living values learning. The data were collected by observation, interview, and documentation. The researcher used observation sheets and interview guides as the instruments of this research. The data were analyzed by descriptive-analyzed technique and applied Miles and Huberman model. Many steps of data analysis were conducted, included measuring data reduction, displaying data, and conclusion. The validity of the data were checked by triangulation.

The result showed that the implementation of educational values of nasionalism in the living values learning process involving the value of the award in diversity (tolerance), unity, and peace. Living values learning process includes three stages: planning, implementation, and evaluation. Learning plan of living values is based on signs EYCG curriculum (Years Earlier Curicullum guidence) and modified with multiple sources of reference. The learning plan includes syllabus and program description. The implementation of living values learning process emphasizes three elements of embeding moral values such as knowledge, feeling, and moral behavior. The evaluation of the living values learning process includes the assessment of learning outcome and learning process. Assessment of learning outcome has reached the domain of comprehension and moral behavior. Learning process assessment is conducted orally but rarely carried out by the teacher.
\end{abstract}

Keyword: value education, nationalism, living values learning process

\begin{abstract}
Abstrak
Penelitian ini bertujuan untuk mengetahui pelaksanaan pendidikan nilai nasionalisme dalam pembelajaran living values pada kelas prep di SD Tumbuh 1 Yogyakarta. Jenis penelitian ini adalah kualitatif menggunakan metode deskriptif. Subjek penelitian terdiri atas kepala sekolah, guru dan siswa. Objek penelitian ini adalah proses pembelajaran living values. Teknik pengumpulan data terdiri atas observasi, wawancara, dan dokumentasi. Instrumen pengumpulan data terdiri atas pedoman observasi dan pedoman wawancara. Analisis data dilakukan secara deskriptif dengan menggunakan teknik analisis data model Miles and Huberman. Tahap analisis data tersebut mencakup reduksi data, display data, dan penarikan kesimpulan. Teknik pemeriksaan keabsahan data dengan menggunakan teknik triangulasi.
\end{abstract}


Penelitiaan ini menunjukkan hasil bahwa pelaksanaan pendidikan nilai nasionalisme dalam pembelajaran living values mencakup nilai penghargaan dalam keragaman (toleransi), persatuan, dan kedamaian. Proses pembelajaran living values mencakup tiga tahap yaitu perencanaan, pelaksanaan, dan evaluasi pembelajaran. Perencanaan pembelajaran living values berdasarkan pada rambu-rambu kurikulum EYCG (Earlier Years Curicullum guidence) dan dimodifikasi dengan beberapa sumber referensi. Perencanaan pembelajaran mencakup penyusunan silabus dan gambaran program. Pelaksanaan pembelajaran living values menekankan pada tiga unsur penanaman nilai moral yaitu pengetahuan, perasaan, dan tindakan moral. Evaluasi dalam pembelajaran living values meliputi penilaian hasil belajar dan proses pembelajaran. Penilaian hasil belajar sudah menjangkau ranah pemahaman dan perilaku moral. Penilaian proses pembelajaran dilaksanakan secara lisan tetapi jarang dilakukan oleh guru.

Kata kunci: Pendidikan nilai, Nasionalisme, Pembelajaran living values

\section{PENDAHULUAN}

Indonesia adalah Negara kesatuan yang terdiri dari berbagai suku bangsa, ras, bahasa, agama, dan budaya. Masyarakat Indonesia dikenal dengan masyarakat majemuk. Kemajemukan yang dimiliki oleh Negara Indonesia sering menimbulkan pertikaian dan perpecahan antar daerah sehingga memberikan peluang bagi pihak asing untuk merusak persatuan dan keutuhan Negara Indoenesia. Beberapa daerah di Indonesia sering terjadi kekerasan antar kelompok yang menunjukkan lemahnya rasa persatuan dan toleransi terhadap perbedaan. Menanggapi pernyataan tersebut, Gina Lestari ${ }^{1}$ menyatakan bahwa tingkat keragaman bangsa Indonesia yang tinggi menyimpan potensi konflik etnis dan SARA yang dapat mengancam kehidupan berbangsa dan bernegara.

Hal ini telah terbukti di beberapa wilayah Indonesia pernah terjadi konflik seperti konflik antar suku di Sampit (Suku Madura dan Dayak), konflik antar agama di Ambon dan Poso, konflik antar Etnis pada tahun 1998, dan konflik di Aceh antara GAM dan $\mathrm{RI}^{2}$. Selanjutnya, beberapa hari terakhir ini di Jakarta dihiasi dengan

${ }^{1}$ Gina Lestari, Bhinnekha Tunggal Ika: Khasanah Multikultural Indonesia Di Tengah Kehidupan SARA, dalam Jurnal Pendidikan Pancasila dan Kewarganegaraan, Vol 28, Nomor 1, 2015, hlm 31

${ }^{2}$ Lebih lanjut lihat http://news.okezone.com/ $\mathrm{read} / 2016 / 02 / 25 / 340 / 1320731 /$ lima-konflik-sara-palingmengerikan-ini-pernah-terjadi-di-indonesia spanduk yang berbau suku, agama, ras dan antar golongan. Spanduk itu tersebar di berbagai sudut ibu kota, seperti jalan raya dan jembatan penyeberangan orang ${ }^{3}$.

Beberapa surat kabar nasional juga memberitakan bahwa generasi muda Indonesia banyak melakukan tawuran antar pelajar. Sebagai contoh telah terjadi tawuran antar pelajar di jalan layang (flyover) Pasar Rebo, Ciracas, Jakarta Timur, yang videonya viral di media sosial. Dalam peristiwa yang terjadi pada tanggal 14 Februari itu, satu orang pelajar tewas. ${ }^{4}$.

Salah satu strategis yang bisa dilakukan pemerintah Indonesia untuk meminimalisir konflik SARA dan tawuran antar pelajar tersebut sehingga persatuan dan kesatuan bangsa bisa dijaga dan dipertahankan yaitu melalui pendidikan. Pendidikan adalah proses komunikasi yang di dalamnya mengandung transformasi nilai-nilai dan keterampilanketerampilan di dalam dan di luar sekolah yang berlangsung sepanjang hayat ${ }^{5}$.

Pendidikan nasional dilaksanakan berdasarkan UU No. 20 Tahun 2003 yang

${ }^{3}$ Lebih lanjut lihat http://www.cnnindonesia.com/ kursipanasdki1/20170406081402-516-205324/perangspanduk-sara-jelang-pemungutan-suara/).

${ }^{4}$ Lebih Lanjut lihat https://news.detik.com/ berita/d-3431303/tawuran-pelajar-di-jaktim-1-orangtewas).

${ }^{5}$ Dwi Siswoyo, dkk, Ilmu Pendidikan (Jakarta, UNY Press, 2007) hlm. 27 
berperan mengembangkan potensi peserta didik sehingga memiliki kekuatan spiritual keagaman, pengendalian diri, kepribadian, akhlak mulia, serta keterampilan yang diperlukan dirinya, masyarakat, bangsa, dan Negara ${ }^{6}$.

Amanat tersebut menunjukkan bahwa pendidikan pada hakikatnya mempunyai peran strategis dalam membangun nilai-nilai moral. Pendapat lain juga menyatakan bahwa pendidikan juga mengembangkan peserta didik rasa cinta kepada bangsa dan tanah air (nasionalisme) yang diekspresikan dalam perilaku mencintai hidup bersama dalam kemajemukan dan bekerjasama guna kemajuan bangsanya ${ }^{7}$.

Lingkungan pendidikan yang cukup berperan menanamkan nilai-nilai kehidupan sehingga terbentuk sikap nasionalisme bagi peserta didik adalah lembaga sekolah. Dalam masyarakat modern, sekolah dipercaya sebagai lembaga yang penting untuk menanamkan dan mengembangkan nilai-nilai kehidupan disamping lingkungan keluarga dan masyarakat. Masa-masa sekolah adalah masa pembentukan kepribadian yang sangat menentukan fondasi moral-intelektual seseorang ${ }^{8}$.

Sekolah sebagai tempat berinteraksi peserta didik satu dengan yang lain, dipastikan melibatkan beragam nilai kehidupan yang lahir secara pribadi dan ditampilkan dalam bentuk pikiran, ucapan, dan perbuatan. Beragam nilai kehidupan yang ditampilkan oleh berbagai peserta didik tentunya cukup berpengaruh terhadap terbentuknya iklim budaya sekolah.

Selama ini, sekolah telah mengembangkan dan membangun suatu kepribadian bagi peserta didik. Kepribadian ini dikembangkan dalam bentuk sikap mental, noma-norma sosial,

${ }^{6}$ Herminarto Sofyan, Implementasi Pendidikan Karakter melalui Kegiatan Mahasiswa dalam Pendidikan Karakter dalam Perspektif Teori dan Praktik (Yogyakarta: UNY Press, 2011) hlm. 109

${ }^{7}$ Zamroni, Strategi dan Model Implementasi Pendidikan Karakter di Sekolah dalam Pendidikan Karakter ....... hlm. 172

${ }^{8}$ Ajat Sudrajat, Membangun Budaya Sekolah Berbasis Karakter Terpuji dalam Pendidikan Karakter ......hlm. 133 dan pola perilak ${ }^{9}$. Berbagai nilai kehidupan yang ditunjukkan oleh warga sekolah cukup berpengaruh terhadap perilaku siswa dan hubungan-hubungan yang terjadi di dalamnya. Berdasarkan pernyataan tersebut, sekolah memiliki peran yang sentral dalam membentuk sikap nasionalisme.

Penanaman nilai nasionalisme dalam pendidikan merupakan kunci untuk mengatasi keberagaman adat istiadat, bidaya, agama, serta etnis. Tanpa nasionalisme sebagai alat pemersatu, sulit kiranya untuk mencari titik temu dari berbagai kebiasaan yang berasal dari berbagai etnik ${ }^{10}$.

Melihat kondisi demikian, proses pendidikan yang harus dilaksanakan harus melibatkan nilainilai yang baik, intelektual, dan keterampilan. Pendidikan yang menyeimbangkan kebutuhan peserta didik baik transfer of knowledge maupun transfer of values.

Pembentukan sikap nasionalisme merupakan proses untuk mengembangkan pada diri setiap peserta didik sebagai warga yang bermartabat, merdeka, berdaulat untuk menjaga, mempertahankan kemerdekaan dan kedaulatan bangsa ${ }^{11}$.

Dengan demikian, pembelajaran di sekolah perlu mengembangkan peserta didik untuk memiliki kesadaran diri, niat, kemampuan, dan perilaku untuk mempertahankan kemerdekaan dan kedaulatan bangsa. Penanaman sikap nasionalisme yang akan dikembangkan pada diri peserta didik mencakup proses melihat, memahami, menyadari, dan berani mengambil keputusan untuk melakukannya. Pendidikan nilai nasionalisme dilaksanakan dalam bentuk pendidikan holistic yang menggunakan metode knowing the good, feeling the good, dan acting the good $^{12}$.

${ }^{9}$ Ajat Sudrajat, Membangun Budaya Sekolah Berbasis Karakter Terpuji dalam Pendidikan Karakter ......hlm. 135

${ }^{10}$ Sunarso, dkk. Pendidikan Kewarganegaraan Buku Pegangan Mahasiswa Paradigma Baru (Yogyakarta: UNY Press, 2006) hlm. 27

${ }^{11}$ Zamroni, Strategi dan Model Implementasi Pendidikan Karakter di Sekolah dalam Pendidikan Karakter ....... hlm. 159

${ }^{12}$ Suharjana, Model Pengembangan Karakter 
Pelaksanaan pendidikan nilai nasionalisme di dalam proses pembelajaran kurang mendapat perhatian dari pihak sekolah. Pendidikan sekolah belum bisa melaksanakan peran pendidikan nilai nasionalisme pada diri peseta didik. Pendidikan sekolah masih terjebak dalam peran mentransfer pengetahuan seperti persiapan ujian nasional. Dengan demikian pihak sekolah perlu melakukan inovasi dalam dunia pendidikan agar sekolah berperan dalam pembangunan sikap nasionalisme ${ }^{13}$.

SD Tumbuh merupakan salah satu sekolah di Yogyakarta yang telah melakukan inovasi dengan sistem pendidikan inklusi dengan berbagai program pendidikan yang tidak hanya menekankan pada aspek intelektual tetapi menekankan pada aspek kepribadian.

Inovasi pendidikan SD Tumbuh tidak hanya melibatkan anak berkebutuhan khusus tetapi juga keragaman agama, budaya, bangsa, dan status sosial ekonomi. Hal ini dikuatkan dengan hasil pengamatan peneliti bahwa peserta didik SD tumbuh dari kelas prep hingga kelas enam bersifat diversity dengan beragam kondisi baik fisik, sosial, budaya, agama, dan ras. Untuk mendukung dan mendampingi peserta didik dalam menghadapi, menerima, dan menghargai perbedaan maka program pendidikan di SD Tumbuh I Yogyakarta tidak hanya mempersiapkan individu dari aspek akademis anak tetapi juga mempersiapkan individu yang matang secara emosi dan sosial dengan lingkungan sekitar yang sudah mendunia.

Salah satunya melalui program pendidikan nilai baik di dalam maupun luar pembelajaran. Hasil pengamatan peneliti juga dikuatkan oleh pernyataan edukator kelas prep bahwa penanaman nilai dalam pembelajaran diberikan melalui bidang studi living values. Pembelajaran bidang studi living values pada kelas prep di SD Tumbuh I memfokuskan pada transfer of values diseimbangkan dengan transfer of

melalui Pendidikan Jasmani dan Olahraga dalam Pendidikan Karakter ..... hlm. 50

${ }^{13}$ Zamroni, Strategi dan Model Implementasi Pendidikan Karakter di Sekolah dalam Pendidikan Karakter ....... hlm. 173 knowledge yang bertujuan untuk menumbuhkan, mengembangkan, dan membina karakter siswa untuk bisa bersikap toleransi, menjaga persatuan, dan hidup damai dalam perbedaan.

Berdasarkan paparan di atas, peneliti berkeinginan untuk mengungkap lebih jauh tentang pelaksanaan pendidikan nilai nasionalisme dalam proses pembelajaran living values pada kelas prep di SD Tumbuh I Yogyakarta. Siswa kelas prep dengan karakteristik usia 6-7 tahun berada dalam tahap pertumbuhan dan perkembangan yang bersifat unik. Di masa-masa inilah, anak seyogyanya mulai di arahkan dalam bersikap dan berperilaku sesuai dengan nilai-nilai positif yang berlaku secara universal.

Dari uraian tersebut, peneliti tertarik untuk melakukan pengkajian mengenai pelaksanaan pendidikan nilai untuk menumbuhkan sikap nasionalisme dalam pembelajaran living value pada kelas prep.

\section{METODE PENELITIAN}

Penelitian ini menggunakan pendekatan kualitatif menggunakan metode deskriptif. Penelitian ini dilakukan di SD Tumbuh I Yogyakarta di Jalan A.M Sangaji No. 48 Yogyakarta. Beberapa subjek penelitian yang akan dijadikan sebagai sumber data dalam penelitian ini, antara lain: kepala sekolah, guru dan siswa kelas prep (Kelas persiapan).

Teknik pengumpulan data yang digunakan adalah observasi partisipatif yaitu peneliti datang ke tempat kegiatan orang yang di amati, tetapi tidak ikut terlibat dalam kegiatan tersebut. Observasi dilakukan oleh peneliti kepada aktivitas belajar dan sikap siswa selama proses pembelajaran. Observasi dalam penelitian ini adalah observasi langsung yaitu pengamat melihat dan mengamati secara langsung kemudian mencatat perilaku dan kejadian yang terjadi.

Instrumen yang digunakan dalam penelitian ini adalah peneliti sendiri, dimana peneliti akan melakukan observasi (pengamatan), dokumentasi dan wawancara. Wawancara yang dilakukan dalam penelitian kualitatif ini secara terstruktur, dimana peneliti menetapkan 
sendiri masalah dan pertanyaan-pertanyaan yang akan di ajukaan untuk mengungkap data. Walaupun demikian, peneliti juga bisa mengembangkan pertanyaan-pertanyaan tersebut guna memperoleh data yang lebih bermakna dan sesuai dengan permasalahan yang sedang di teliti.

Teknik analisis data yang digunakan adalah analisis deskriptif model Miles and Huberman yang meliputi reduksi data, display data, dan mengambil kesimpulan atau verifikasi ${ }^{14}$.

Teknik pemeriksaan keabsahan data dalam penelitian ini dilakukan menggunakan teknik trianggulasi yaitu teknik pemeriksaan keabsahan data yang memanfaatkan sesuatu lain dari luar untuk keperluan pengecekan atau sebagai pembanding terhadap data-data tersebut ${ }^{15}$.

\section{PEMBAHASAN}

\section{Pendidikan Nilai}

Nilai merupakan istilah yang tidak dapat dipisahkan dari pendidikan. Dengan kata lain, nilai dan pendidikan merupakan dua hal yang satu sama lainnya tidak dapat dipisahkan. Ketika pendidikan cenderung diperlakukan sebagai wahana transfer pengetahuan, di sana juga terjadi perambatan nilai yang setidaknya bermuara pada nilai-nilai kebenaran intelektual. Untuk memahami pendidikan nilai, yang perlu kita pahami adalah nilai ${ }^{16}$.

Dalam hal ini, pendidikan nilai tidak harus merupakan suatu program atau pelajaran khusus, tetapi lebih merupakan dimensi dari seluruh usaha pendidikan. Dengan kata lain, penanaman nilai tidak hanya tugas guru pendidikan moral dan agama, serta tidak hanya pada saat mengajarkannya di kelas, melainkan pendidikan nilai perlu di berikan kepada peserta didik setiap saat dan di mana saja, serta nilai harus menjadi bagian integral dalam kehidupan peserta didik.

${ }^{14}$ Matthew B. Miles and A. Michael Huberman, Analisis Data Kualitatif(Jakarta: Universitas Indonesia, 1992) hlm. 16-21

${ }^{15}$ Moleong, Metodologi Penelitian Kualitatif (Bandung: Remaja Rosdakarya, 2005) hlm.330

${ }^{16}$ Mulyana, Mengartikulasikan Pendidikan Nilai (Bandung: Alfabeta, 2004) hlm.103
Apabila nilai-nilai tersebut telah mempribadi dalam kehidupan seseorang, maka akan tampak dalam pola sikap dan perilakunya. Nilai-nilai ada yang bersifat dasar yaitu nilai yang berlaku secara universal. Selain itu ada nilai-nilai yang bersifat subyektif yakni nilai yang bergantung pada budaya, waktu, dan tempat ${ }^{17}$.

Nilai-nilai moral yang bisa di berikan kepada peserta didik di sekolah dapat mengacu pada program pendidikan nilai dari UNESCO, yaitu living values education program (LVEP). Living Values Education adalah program pendidikan yang menawarkan aktivitas nilai empiris dan metodologi praktis bagi para pendidik, fasilitator, pekerja sosial, orang tua dan pendamping anak untuk membantu mereka menyediakan kesempatan bagi anak-anak dan remaja dapat menggali serta mengembangkan dua belas nilai-nilai universal: kerjasama, kebebasan, kebahagiaan, kejujuran, kerendahan hati, cinta, kedamaian, penghargaan, tanggung jawab, ksederhanaan, toleransi,dan persatuan ${ }^{18}$.

Nilai-nilai yang menjadi keyakinan seseorang dalam berpikir dan bertindak akan membentuk karakter seseorang. Jika nilai-nilai tersebut menyatu dalam kehidupan manusia maka nilai akan tampak dalam sikap dan perilakunya. Jika nilai yang diyakini baik maka baik pula tindakan dan pikiran seseorang. Jika nilai yang diyakini tidak baik maka jelek pula tindakan dan pikiran seseorang. Dengan demikian, nilai-nilai yang memiliki unsur kebaikan perlu ditanamkan pada diri anak sejak usia dini untuk dijadikan pedoman berpikir, berkata, dan berperilaku dalam keseluruhan kehidupan.

\section{Pengertian Nasionalisme}

Negara Indonesia adalah Negara kesatuan. Negara yang terbentuk dari perasaan bersatu seluruh masyarakat yang berada di seluruh wilayah Negara Indonesia dalam konteks

${ }^{17}$ I Wayan Koyan, Pendidikan Moral: Pendekatan Lintas Budaya (Jakarta: Departemen pendidikan Nasional, 2000) hlm.12

${ }^{18}$ Diane T \& Pilar Quera C, Living values activities for children ages 3-7 (Jakarta: Gramedia, 1994) hlm.175 
diversity. Sebagai bangsa yang majemuk, bangsa Indonesia harus mampu bergaul dalam rangka memajukan persatuan bangsa. Persatuan yang sedemikian kuat maka akan timbul rasa nasionalisme.

Nasionalisme merupakan sikap cinta terhadap tanah air. Cinta tanah air adalah cara berpikir, bersikap, dan berbuat yang menunjukkan kesetiaan, kepedulian, dan penghargaan yang tinggi terhadap bangsa, lingkungan fisik, sosial, budaya, ekonomi, dan politik bangsanya ${ }^{19}$.

Rasa nasionalisme yang harus dimiliki bangsa Indonesia bukan menjurus pada rasa bangga kepada bangsa sendiri dengan merendahkan bangsa lain. Oleh karena itu, bangsa Indonesia perlu menggalang persatuan dan kesatuan bangsa yang tidak memandang perbedaan itu sebagai konflik.

Penanaman nilai nasionalisme sangat erat kaitannya dalam pembentukan karakter siswa yang berguna bagi pembangunan bangsa. Dengan demikian, guru sangat penting untuk menanamkan nilai cinta tanah air ke dalam diri siswa sebagai bekal sebagai generasi penerus bangsa ${ }^{20}$.

Pendidikan dapat meningkatkan pemahaman anak didik mengenai nilai-nilai yang terkandung dalam nasionalisme Indonesia seperti cinta tanah air, menghargai jasa-jasa pahlawan, rela berkorban demi bangsa dan Negara, mengutamakan kepentingan umum, bangga pada budaya yang beraneka ragam, bangga sebagai bangsa Indonesia, dan menerima kemajemukan ${ }^{21}$.

Pendapat lain menyatakan bahwa wujud perilaku yang mencerminkan sikap nasionalisme adalah sebagai berikut: Membina keserasian, keselarasan, dan keseimbangan, saling mengasihi, saling membina dan saling memberi, tidak menonjolkan perbedaan, melainkan mencari kesamaan, meningkatkan kecintaan

${ }^{19}$ Zamroni, Strategi dan Model Implementasi Pendidikan Karakter di Sekolah dalam Pendidikan Karakter ....... hlm. 169

${ }^{20}$ Novita Eka, Penanaman Nilai Cinta Tanah Air di SD Negeri Sedayu 1 Muntilan Magelang. Jurnal Pendidikan Guru Sekolah Dasar Vol. 4, No. 5, 2016. hlm 314-315

${ }^{21}$ Aman, Model Pembelajaran Sejarah (Yogyakarta: Ombak, 2011) hlm. 141 terhadap lingkungan hidup, bekerja sama sesama warga, lingkungan, dan pemerintah, menjauhi pertentangan, dan perkelahian, dan menggalang persatuan dan kesatuan melalui berbagai kegiatan ${ }^{22}$.

Berdasarkan ulasan di atas, dapat disimpulkan bahwa indikator sikap nasionalisme mencakup cinta tanah air, menghargai jasa para pahlawan, rela berkorban demi bangsa, mengutamakan kepentingan umum, membina persatuan dan kesatuan, bangga pada budaya yang beraneka ragam, bangga sebagai bangsa Indonesia, sikap toleransi, cinta terhadap lingkungan, dan berkerja sama.

\section{Pendidikan Nilai Dalam Pembelajaran}

Pelaksanaan pendidikan nilai dalam pembelajaran perlu mengacu beberapa hal yaitu pendekatan dan strategi, metode, dan evaluasi pendidikan nilai. Keberhasilan proses pendidikan nilai dipengaruhi oleh ketepatan sesorang guru dalam memilih dan menerapkan metode-metode penanaman nilai-nilai moral. Pendidikan nilai di era modern ini sudah tidak memadai lagi jika diajarkan dengan metode tradisonal yang cenderung mewujudkan kondisi pembelajaran pada aspek teacher centered bukan pada student centered. Metode pembelajaran tradisional dinilai tidak mampu mencapi tujuan pendidikan karena kurang memberikan wadah atau kesmepatan dalam kelangsungan pengalaman peserta didik yang diperoleh dari kehidupan sehari-hari.

Pendidikan nilai dapat diterapkan dengan menggunakan salah satu pendekatan dan strategi pendidikan nilai yang mencakup memoralisasi, bersikap membiarkan, menjadi model, dan klarifikasi nilai ${ }^{23}$.

Proses penanaman nilai-nilai moral dipengaruhi oleh ketepatan guru dalam memilih pendekatan dalam mengajarkan materi tersebut. Ada delapan pendekatan yang dapat digunakan

${ }^{22}$ Suparlan Al Hakim, Pendidikan Kewarganegaraan dalam Konteks Indonesia. (Malang: Madani, 2016) hlm. 225-226

${ }^{23}$ Slamet Soewandi, Perspektif pembelajaran berbagai Bidang Studi (Yogyakarta: Universitas Sanata Darma , 2005) hlm. 110 
dalam mengajarkan pendidikan nilai yaitu evocation, incultion, moral reasoning, value clarification, moral awareness, commitment approach, dan union approach ${ }^{24}$.

$P$ endekatan pembelajaran perlu memperhatikan tiga komponen dalam menanamkan nilai moral, yaitu pengetahuan moral (moral knowing), perasaan moral (moral feeling), dan tindakan moral (moral action).

Komponen pengetahuan moral (moral knowing) adalah kesadaran moral atau alasan seseorang melakukan sesuatu berdasarkan nilainilai moral. Siswa di bantu mengerti mengapa suatu nilai perlu dilakukan. Komponen perasaan moral lebih pada keadaran tentang hal baik dan tidak baik. Perasaan moral cukup berpengaruh untuk berbuat baik. Perasaan moral perlu dikembangkan dengan memupuk sikap empati dan hati nurani ${ }^{25}$. Sedangkan komponen tindakan moral, kemampuan untuk melakukan perasaan moral ke dalam perilaku.

Beberapa metode dan teknik yang cocok untuk mengajarkan nilai-nilai moral antara lain: (1) Permainan skenario dan permainan kata karena hal itu memungkinkan anak-anak betul-betul menempatkan diri dalam suatu situasi dan melihat konsekuensi serta hubungan sebab-akibat dalam berbagai perilaku. (2) Diskusi tentang konsep mengajak anak-anak berdiskusi tentang konsep-konsep moral sesuai dengan usia mereka, guru membantu mereka mengembangkan minat dan kemampuan mereka untuk berbicara sungguh-sungguh dengan orang lain. (3) Pujian yang positif adalah salah satu metode yang berguna untuk membuat suatu perilaku bermoral mejadi kebiasaan yang konsisten dan sadar. (4) Ganjaran, penghargaan, dan bentuk pengakuan lain bila digabungkan dengan pujian dapat menjadi cara yang berguna untuk mendukung perilaku bermoral. Selain berbagai jenis ganjaran, penghargaan dapat dijadikan pangkal diskusi yang menarik. (5) Kesempatan kedua untuk memperbaiki kesalahan, memperbaiki kesalahan anak dan

${ }^{24}$ Zubaedi, Pendidikan Berbasis Masyarakat (Jakarta: Pustaka Pelajar, 2006) hlm.10-11

${ }^{25}$ Asri Budiningsih, Pembelajaran Moral (Jakarta: Rineka Cipta, 2004) hlm. 6-7 mengingatkan mereka kepada nilai-nilai moral tanpa efek negatif dalam bentuk hukumum secara verbal atau nonverbal. (6) Menghafalkan pepatah-pepatah yang menyatakan suatu nilai bisa berguna untuk menanamkan nilai tersebut dengan kuat ke dalam diri anak-anak. (7) Nilai dan kebalikannya, memandu anak-anak untuk menemukan lawan kata atas suatu nilai, bertanya kepada anak mana yang merugkan orang lain dan mana yang menolong orang lain. (8) Pengakuan atas perilaku positif, pengabaian perilaku negatif. Memberikan perhatian ketika anak-anak berbuat benar atau berperilaku positif $^{26}$.

Tidak sekadar pendekatan dan metode pembelajaran yang digunakan, tujuan pendidikan nilai akan tercapai jika proses pembelajarannya juga berbasis nilai. Pembelajaran bebasis nilai membutuhkan kesadaran pendidik terhadap nilai-nilai mereka sendiri yang pada akhirnya akan menunjang para guru untuk membawa nilai tersebut ke ruangan kelas, sehingga suasana belajar berbasis nilai akan terwujud.

Dengan demikian peserta didik akan menyadari nilai-nilai kehidupan melalui proses pertimbangan nilai yang tepat dan pembiasaan bertindak yang konsisten. Pendidikan nilai yang perlu ditanamkan pada peserta didik mencakup nilai-nilai moral yang baik dan benar, berakar pada agama, adat istiadat, dan budaya bangsa Indonesia serta di terima secara universal dalam rangka mengembangkan kepribadian peserta didik supaya menjadi manusia yang "baik".

Keberhasilan akhir dari proses pembelajaran tidak terlepas dari kegiatan evaluasi pembelajaran. Evaluasi berperan penting bagi guru untuk mengetahui tercapai tidaknya tujuan pembelajaran dan umpan balik bagi guru untuk pembelajaran selanjutnya.

Evaluasi pendidikan nilai sangat diperlukan untuk mengetahui dan mendapatkan gambaran mengenai kemajuan serta perkembangan peserta didik yang menyeluruh tentang penghayatan nilai yang tercermin dalam kehidupan sehari-hari. Di samping itu, hasil

${ }^{26}$ Linda \& Ricahard. E, Mengajarkan Nilai-Nilai Kepada Anak (Jakarta: Gramedia Pustaka Utama, 1995) hlm. xxvi-xxxii 
evaluasi dapat dijadikan sebagai umpan balik kepada guru untuk mengungkapkan kelebihan dan kekurangan dari aspek-aspek pendidikan nilai yang sudah dijalankan agar dapat menyempurnakan pelaksanaan program pendidikan nilai ke depannya.

Evaluasi pendidikan nilai mencakup tiga kawasan yakni penalaran, perasaan, dan perilaku. (1) Evaluasi penalaran mencakup pengetahuan dan wawasan peserta didik dalam menentukan serta memilih nilai-nilai. Evaluasi penalaran dapat dilakukan dengan menggunakan instrumen tes. (2) Evalusi perasaan berupa pengamatan afek peserta didik dalam menerapkan nilai-nilai dalam jangka waktu yang lama. Pengamatan yang di lakukan hanya berupa afek peserta didik terkait dengan mana nilai yang baik, kurang baik, dan tidak baik serta intensitas mereka dalam menerapkan nilai tersebut. Untuk menentukan seseorang berada pada tahap perkembangan afektif perlu menggunakan instrumen yang menuntur adanya respon yang berkaitan dengan perasaan. Disamping itu, evaluasi perasaan dapat diukur dengan menggunakan skala sikap. Karakteristik afektif yang dapat dievaluasi meliputi minat, motivasi, apresiasi, kesadaran akan harga diri, dan nilai. (3) Evaluasi perilaku berupa tingkah laku atau tindakan peserta yang mencerminkan perasaan peserta didik tentang nilai-nilai yang dianutnya. Evaluasi perilaku dapat dilakukan dengan menggunakan instrumen pengamatan (observasi) dan tes. Perilaku moral dapat dievaluasi secara akurat dengan menggunakan pengamatan jangka panjang dalam waktu yang cukup lama. Melalui pengamatan jangka panjang, dapat diketahui apakah perilaku tersebut sudah menunjukkan sebuah karakter yaitu jujur, adil, disiplin, bertanggung jawab, toleransi, menghargai, taat pada aturan, rukun, dan sebagainya ${ }^{27}$.

\section{Living Values Education Program (LVEP)}

Living Values Education Program adalah program pendidikan yang menawarkan aktivitas nilai empiris dan metodologi praktis bagi para

${ }^{27}$ Linda \& Ricahard. E, Mengajarkan Nilai-Nilai Kepada Anak ..... hlm. Xxvi-Xxxii pendidik, fasilitator, pekerja sosial, orang tua dan pendamping anak untuk membantu mereka menyediakan kesempatan bagi anak-anak dan remaja dapat menggali serta mengembangkan dua belas nilai-nilai universal: kerjasama, kebebasan, kebahagiaan, kejujuran, kerendahan hati, cinta, kedamaian, penghargaan, tanggung jawab, ksederhanaan, toleransi, dan persatuan ${ }^{28}$.

Living values atau nilai-nilai dasar kehidupan adalah berbagai kebiasaan yang secara umum (universal) mendasari relasi yang baik dan harmonis antara kita dengan orang lain di sekitar kita. Ini merupakan kebiasaankebiasaan yang sulit untuk kita temukan di masamasa kita saat ini dan mendatang, terhimpit oleh sikap dan sifat manusia modern yang individualistis, hedonistis dan materialistis; lupa bahwa manusia adalah makhluk sosial, berbudi dan berakhlak ${ }^{29}$.

Living Values Education Program percaya bahwa nilai tidak diajarkan, melainkan ditangkap atau dirasakan. Murid belajar dari contoh yang diberikan pendidiknya. Oleh karena itu, sangat penting bagi tiap pendidik untuk menyadari dan terus menghidupkan nilai pribadi mereka, untuk dapat menjalani peran sebagai panutan ini secara positif. Kurikulum Living Values Education mencakup berbagai aktivitas bermuatan nilai untuk damai, menghargai, kasih sayang, kerjasama, kebahagiaan, kejujuran, kerendahan hati,tanggung jawab, kesederhanaan, toleransi, kebebasan dan persatuan.

Senada dengan pernyataan tersebut, Living Values Education Program sebagai program pendidikan nilai memiliki maksud yang tersurat yakni untuk memberikan bimbingan prinsip dan sarana untuk pengembangan manusia utuh, menyadari bahwa seorang manusia terdiri dari dimensi fisik, intelektual, emosional, dan spiritual.

Kerja keras guru dalam merencanakan, melaksanakan, dan mengadakan evaluasi pembelajaran Living Values Education Program berpengaruh besar dalam pencapaian

${ }^{28}$ Diane T \& Pilar Quera C, Living values activities for children ages 3-7 (Jakarta: Gramedia, 1994) hlm. 175

${ }^{29}$ Diane T \& Pilar Quera C, Living values activities for children ages 3-7 .... hlm. 187 
tujuan pembelajaran. Jika guru melaksanakan pembelajaran tanpa adanya perencanaan yang lebih matang maka tujuan pembelajaran tidak akan tercapai ${ }^{30}$.

Melalui sistem perencanaan yang matang dan sistematis, guru akan terhindar dari keberhasilan secara untung-untungan, guru dapat menggambarkan berbagai hambatan yang mungkin akan di hadapi sehingga dapat menentukan berbagai strategi yang bisa di lakukan untuk mencapai tujuan yang di harapkan, dan guru dapat menentukan berbagai langkah dalam memanfaatkan berbagai sumber dan fasilitas yang ada untuk ketercapaian tujuan.

Pendapat lain menyatakan bahwa "Learning may be defined as relatively enduring change in potential behavior that results from experience." Artinya bahwa belajar merupakan proses perubahan yang relatif abadi dalam mengembangkan perilaku potensial yang dihasilkan dari pengalaman. Interaksi guru dan siswa sebagai makna utama proses pengalaman pembelajaran yang memegang peranan penting untuk mencapai tujuan pembelajaran yang efektif ${ }^{31}$.

Interaksi guru dan siswa sebagai makna utama proses pembelajaran yang memegang peranan penting untuk mencapai tujuan pembelajaran yang efektif. Mengingat kedudukan siswa sebagai subjek dan sekaligus juga sebagai objek dalam pembelajaran maka inti proses pembelajaran tidak lain adalah kegiatan belajar siswa dalam mencapai tujuan pembelajaran.

Peranan guru bukan semata-mata memberikan informasi, melainkan mengarahkan dan memberi fasilitas belajar agar proses belajar lebih memadai. Belajar bukan menghafal dan bukan pula mengingat. Belajar adalah suatu proses yang ditandai dengan adanya perubahan pada diri seseorang. Perubahan sebagai hasil proses belajar dapat ditunjukkan

${ }^{30}$ Wina Sanjaya, Strategi Pembelajaran: Berorientasi Standar Proses Pendidikan (Jakarta: Kencana, 2006) hlm. 49

${ }^{31}$ Crooks \& Stein, Psychology science, behavior, and life ed) (London: Holt, Rinehart, and Winston,199) hlm.193 dalam berbagai bentuk seperti berubah pengetahuan, pemahamannya, sikap, dan tingkah lakunya, keterampilannya, kecakapan, dan kemampuannya, daya reaksinya, daya penerimaannya, dan aspek lain yang ada pada individu ${ }^{32}$.

Pembelajaran merupakan kegiatan yang di rancang untuk membantu seseorang mempelajari suatu kemampuan dan atau nilai yang baru serta membantu seseorang dalam mengkonstruksi pengetahuan melalui tahap perencanaan, pelaksanaan, dan evaluasi pembelajaran. Keterpaduan antara langkah yang perencanaan, pelaksanaan, dan evaluasi berpengaruh besar dalam mencapai tujuan pembelajaran yang telah dirumuskan pada satuan pembelajaran.

Pendapat lain menambahkan bahwa: "Learning is the development of new knowledge, skills, or attitudes as an individual interacts with information and the environment." Yang berarti bahwa pembelajaran merupakan pengembangan pengetahuan, keterampilan, atau sikap sebagai interkati dari individu dengan informasi dan lingkungan sekitar ${ }^{33}$.

Dengan demikian, kegiatan pembelajaran berbasis nilai harus menggambarkan kedudukan dan peran pendidik dan peserta didik dalam proses pembelajaran. Pihak guru sebagai perancang program pembelajaran, maka pendidik perlu merangcang pembelajaran berbasis nilai dengan menetapkan metode belajar, media, bahan belajar, strategi pengorganisasian, penyampaian, dan pengelolaan pembelajaran yang berbasis nilai-nilai moral. Sedangkan peserta didik sebagai pijakan utama bagi pendidik dalam merancang pembelajaran moral.

\section{Implementasi Pendidikan Nilai Nasionalisme dalam Pembelajaran Living Values}

Proses pembelajaran living values yang memfokuskan pada nilai nasionalisme akan dijabarkan pada nilai-nilai penghargaan dalam

\footnotetext{
${ }^{32}$ Syaiful Sagala, Metode belajar mengajar.
} (Bandung: Alfabeta, 2008) hlm. 61

${ }^{33}$ Smaldino, Instructional technology and media for learning (Upper Sadle River: Pearson Education, 2005) hlm. 6 
keberagaman, persatuan, dan kedamaian serta dimanifestasikan dalam perencanaan, pelaksanaan, dan evaluasi pembelajaran.

\section{Perencanaan Pembelajaran Living Values}

Perencanaan pembelajaran living values mencakup beberapa tahap yaitu tahap penyusunan silabus, pembuatan gambaran program pembelajaran (mingguan).

Silabus yang disusun tiap dua bulan mencakup silabus nilai penghargaan dalam keberagaman dan persatuan serta silabus tentang materi nilai kedamaian. Penyusunan silabus disesuaikan dengan karakteristisk dan kabutuhan siswa prep. Edukator melakukan penataan kompetensi materi yang disesuaikan dengan kompetensi nilai pada beberapa buku yaitu buku pendidikan sembilan pilar karakter, buku living values activity for ages 3-7 years dan beberapa sumber buku pendukung seperti buku kelas satu.

\section{Penyusunan Silabus}

Silabus living values dimonitoring kepala sekolah. Proses monitoring silabus berlangsung fleksibel. Edukator menyerahkan silabus kepada kepala sekolah tiap dua bulan untuk di monitoring. Kepala sekolah hanya mengecek silabus kemudian dikembalikan lagi kepada edukator. Kepala sekolah sangat mempercayakan edukator dalam penyusunan konsep pembelajaran.

Silabus pembelajaran living values mencakup beberapa sub pokok yang penting yaitu standar kompetensi, kompetensi dasar, indikator, kegiatan pembelajaran, sumber belajar, alokasi waktu, dan penilaian. Silabus semester dua memfokuskan pada tiga kompetensi nilai kehidupan yaitu nilai menghargai keberagaman, persatuan, dan kedamaian.

\section{Penyusunan Gambaran Program}

Edukator menyusun gambaran program pembelajaran. Gambaran program pembelajaran living values diturunkan langsung dari silabus. Isi silabus dan gambaran program mencakup standar kompetensi, kompetensi dasar, kegiatan pembelajaran, indikator, penilaian, dan sumber belajar.
Gambaran program disusun oleh edukator dan dibagikan ke pihak orang tua setiap minggunya. Gambaran program yang dibagikan ke pihak orang tua tiap hari jumat maka disebut program mingguan. Gambaran program berisi tentang halhal penting yang akan dipelajari siswa di sekolah selama satu minggu. Dengan demikian, pihak sekolah membagikan gambaran program kepada orang tua tiap hari jumat. Gambaran program dibagikan kepada orang tua bertujuan memberikan informasi kepada mereka tentang kegiatan belajar siswa selama satu minggu di sekolah.

Melalui gambaran program, orang tua berperan serta dalam membantu siswa untuk belajar di rumah dan menyiapkan mereka untuk belajar di sekolah. Sehingga siswa tahu betul tentang materi yang akan dipelajari pada hari ini dan hari berikutnya.

Berikut akan diuraikan perencanaanperencanaan pembelajaran pada nilai penghargaan dalam keberagaman, persatuan, dan kedamaian.

\section{Nilai Penghargaan dalam Keberagaman}

Indikator pembelajaran pada materi nilai penghargaan dalam keberagaman yaitu siswa mampu mencerminkan sikap dan bicara yang positif pada teman yang mempunyai kebutuhan khusus, teman yang berbeda jenis kelamin, teman yang seagama dan berbeda agama, teman yang sama dan berbeda suku bangsanya.

Metode-metode yang direncanakan mencakup metode menonton film, wawancara teman, minitrip ke tempat ibadah, penugasan, dan metode diskusi.

Evaluasi direncanakan dalam bentuk teknik penilain. Teknik penilaiannya mencakup penilaian unjuk kerja, tugas kelompok, tugas individu, dan tes tertulis.

\section{Nilai Persatuan}

Indikator pembelajaran living values pada materi nilai persatuan yaitu siswa mampu mencerminkan hidup rukun dan memberi contoh hidup rukun di rumah, di sekolah, dan di masyarakat. Materi ajar bersumber dari buku living values, buku PKn kelas satu SD, video film Bulliying, video tawuran, dan lembar kerja. 
Metode-metode yang direncanakan educator mencakup metode role playing (bermain peran), menonton video film Bullying, menonton video film tawuran, metode penugasan, dan metode diskusi.

Evaluasi direncanakan dalam bentuk penilain. Jenis penilaiannya meliputi penilaian unjuk kerja, tugas kelompok, dan tugas individu.

\section{Nilai Kedamaian}

Indikator pembelajaran living values pada materi nilai kedamaian yaitu mampu mengidentifikasi hidup damai dan tidak damai, meningkatkan pengetahuan tentang kedamaian, memiliki keterampilan dalam menyelesaikan konflik dan mampu mengkomunikasikan kedamaian dalam bentuk kata-kata, gambar, simbol, dan poster.

Metode-metode yang direncanakan edukator mencakup metode cerita, role playing (bermain peran), menonton video film dunia yang damai, metode penugasan (membuat boneka, gambar, dan dunia damai), presentasi, membayangkan dunia damai, menonton simbol kedamaian, dan metode diskusi.

Evaluasi direncanakan dalam bentuk penilain. Jenis penilaiannya meliputi penilaian unjuk kerja, tugas kelompok, tugas individu, dan tes lisan.

\section{Pelaksanaan pembelajaran living values}

Berikut pelaksanaan pembelajaran living values yang meliputi nilai penghargaan dalam keberagaman, persatuan, dan kedamaian yang dijabarkan dari awal pembelajaran, inti pembelajaran, dan akhir pembelajaran.

\section{Nilai Penghargaan dalam keberagaman}

Kegiatan pembelajaran living values nilai penghargaan dalam keberagaman dimulai dengan menyanyikan lagu. Lagu yang dinyanyikan antara lain lagu little indian dan lihat kebunku. Kegiatan ini bertujuan membuat anak merasa senang sehingga mereka siap untuk belajar. Kegiatan selanjutnya, guru memberikan pijakan materi. Pijakan berperan sebagai media pengantar bagi siswa untuk melakukan kegiatan inti pembelajaran.
Adapun pijakan yang diberikan mencakup pijakan bentuk review materi dan pijakan berupa materi baru.

Pijakan bentuk review materi ditunjukkan dengan mengulang materi sebelumnya. Pijakan berguna untuk mengingatkan kembali pengetahuan siswa

Pijakan materi baru bertujuan memberikan pengantar bagi siswa untuk melakukan kegiatan inti pembelajaran. Pijakan materi baru disampaikan edukator dengan menggunakan beberapa metode pembelajaran yaitu metode ceramah dan tanya jawab.

Metode yang digunakan dalam pembelajaran living values nilai penghargaan dalam keberagaman meliputi nonton film, penugasan (wawancara), dan diskusi kelompok. Melalui metode-metode tersebut siswa belajar tentang kebergaman agama dan suku bangsa pada kelas prep. Pembelajaran menjadi lebih kontekstual dan siswa aktif memperoleh pengetahuan melalui wawancara. Melalui kegiatan nonton film dan wawancara, siswa dilatih untuk berani bertanya, bersikap, dan berbicara yang positif dengan teman yang sama dan berbeda agama dan suku bangsanya.

Edukator menerapkan beberapa metode tertentu dalam pembelajaran guna menanamkan nilai-nilai moral secara langsung. Memberikan pujian positif bertujuan agar siswa mengulangi perbuatan positif dengan penuh kesadaran. Memberikan kesempatan kedua bertujuan menyadarkan siswa tentang kesalahannya dan memberi kesempatan kepada mereka untuk memperbaiki kesalahan.

Edukator mengakhiri kegiatan pembelajaran dengan meriview materi keberagaman dengan memberikan pertanyaan di akhir pembelajaran dengan teknik tanya jawab. Hasil pengamatan, kegiatan mengulang materi berperan untuk menguatkan materi keberagaman agama dan suku bangsa dalam diri siswa.

\section{Nilai Persatuan}

Kegiatan pembelajaran living values nilai persatuan dimulai dengan menyanyikan lagu anak-anak. Lagu yang dinyanyikan adalah 
lagu morning dan aku sayang kamu. Kegiatan ini bertujuan membuat siswa lebih siap dan konsentrasi untuk belajar. Selanjutnya, edukator memberikan pijakan materi. Pijakan berperan sebagai media pengantar bagi siswa untuk melakukan kegiatan inti pembelajaran. Adapun pijakan yang diberikan mencakup pijakan bentuk review materi dan pijakan berupa materi baru.

Pijakan ini ditunjukkan dengan mengulang materi sebelumnya. Pijakan dalam bentuk review materi berperan sebagai pengantar bagi siswa untuk melakukan kegiatan selanjutnya. Pijakan materi baru bertujuan untuk memudahkan siswa memahami materi baru, materi yang pertama kali diterima siswa prep dalam pembelajaran.

Kegiatan inti pembelajaran materi nilai persatuan dilaksanakan sesuai dengan perencanaan pada gambaran program. Kegiatan inti pembelajaran didukung oleh beberapa metode pembelajaran. Metode-metode berorientasi pada konsep pembelajaran aktif (active leraning) dengan pendekatan inquiry.

Metode yang digunakan dalam pembelajaran living values pada materi nilai persatuan meliputi role play, nonton film, penugasan, dan diskusi kelompok. Melalui metode-metode tersebut diharapkan siswa mampu membedakan antara hidup rukun dan tidak rukun, memberikan contoh hidup rukun dan tidak rukun, dan mencerminkan perilaku hidup rukun di lingkungan rumah, sekolah, dan masyarakat.

Metode-metode yang digunakan guru dalam membelajarkan living values materi nilai persatuan didukung dengan metode-metode terbaik untuk mengajarkan nilai-nilai moral.

Usai menjalankan kegiatan inti pembelajaran, siswa dan guru melakukan kegiatan selanjutnya, yaitu: guru memberikan kuis yang berhubungan dengan materi kerukunan di rumah, sekolah, dan masyarakat.

Kegiatan review materi dengan kuiz dapat membantu siswa untuk mengingat materi kerukunan, contoh hidup rukun di rumah, sekolah, dan masyarakat serta konsekuensi hidup rukun dan hidup tidak rukun.

\section{Nilai Kedamaian}

Kegiatan pembelajaran living values dengan materi nilai kedamaian disampaikan selalu diawali dengan menyanyikan lagu. Lagu yang dinyanyikan antara lain lagu little indian, pak tani, dan aku sayang kamu. Kegiatan bernyanyi bertujuan agar siswa relaks, senang, dan siap menerima pijakan materi. Salah satu lagu yang dianyayikan memiliki hubungan dengan materi kedamaian yaitu "aku sayang kamu". Melalui lagu tersebut, edukator menggunakan konsep sayang untuk memberikan pijakan materi tentang kedamaian. Pijakan berperan sebagai pengantar bagi siswa untuk melakukan kegiatan pembelajaran selanjutnya. Adapun pijakan yang diberikan mencakup pijakan bentuk review materi dan pijakan berupa materi baru.

Melalui pijakan, siswa memperoleh gambaran dan pengetahuan awal tentang materi berikutnya. sehingga siswa dapat menjalani kegiatan inti pembelajaran dengan lancar serta lebih memahami isi materi dan tujuan pembelajaran.

Metode yang digunakan dalam pembelajaran living values nilai kedamaian meliputinontonfilm, permainan peran, penugasan (membuat bintang damai, gambar dunia damai dan simbol kedamaian, poster penyelesaian konflik), dan diskusi. Metode-metode tersebut membantu guru untuk menguatkan pemahaman siswa tentang damai, siswa dapat membedakan antara hidup damai dan hidup tidak damai, dan siswa dapat memperagakan hidup yang damai dengan boneka dan mengkomunikasikan nilai kedamaian melalui poster, gambar dunia damai, dan simbol kedamaian.

Metode-metode yang digunakan edukator dalam membelajarkan living values didukung dengan metode-metode terbaik Melalui metode ini, siswa tidak hanya memahami perbedaan damai dan tidak damai, mereka juga merasakan dampak dari hidup damai dan hidup tidak damai bagi dirinya dan orang lain. Hidup damai dipenuhi dengan cahaya senyum, bahagia, berani, cinta, dan damai sedangkan hidup tidak damai dipenuhi dengan cahaya sunyi, sedih, putus asa, 
perang, dan tidak damai. Metode kedua bertujuan meningkatkan semangat belajar siswa untuk menyelesaikan tugas yang lain dengan hasil yang maksimal.

Kegiatan meriview materi meliputi bermain boneka, refleksi hasil gambar simbol kedamaian, dan memberikan kuis (pertanyaan) di akhir pembelajaran. Tujuannya menguatkan pemahaman siswa tentang materi kedamaian, contoh hidup damai dan tidak damai, cahaya dalam hidup damai dan hidup tidak damai, mampu memperagakan hidup damai melalui boneka damai, konsep cahaya dalam dunia damai dan tidak damai serta mengenal simbol serta pesan kedamaian.

\section{Pelaksanaan Evaluasi Pembelajaran Living Values}

Kegiatan Evaluasi yang dilakukan edukator kelas prep dalam pembelajaran living values mencakup dua hal yaitu evaluasi hasil belajar dan evaluasi proses pembelajaran.

Evaluasi pembelajaran living values menggunakan dua jenis penilaian yaitu penilaian konsep (pemahaman) dan penilaian perilaku. Penilaian konsep menggunakan teknik tes tertulis dan penilaian perilaku menggunakan teknik student record. Teknik tes tertulis ditunjukkan dalam bentuk sejumlah soal. Teknik student record ditunjukkan dalam bentuk catatan-catatan singkat tentang perkembangan pemahaman dan perilaku siswa sehari-hari di sekolah.

Teknik student record dibagi tiga jenis yaitu running record, anecdot record, dan autentik. Penilaian perilaku dengan teknik running record digunakan saat siswa melakukan aktivitas di kelas, teknik anecdot record digunakan saat siswa tidak melakukan aktivitas belajar, dan teknik auntetik record dilakukan berdasarkan lembar kerja. Teknik yang biasa digunakan yaitu teknik running record. Teknik ini digunakan saat siswa melakukan aktivitas di kelas. Hasil pengamatan menunjukkan bahwa edukator kelas prep sudah melakukan evaluasi hasil belajar living values yang mencakup penilaian penalaran dan perilaku.

Jenis evaluasi yang digunakan dalam penilaian penalaran adalah evaluasi bulanan.
Evaluasi bulanan menggunakan teknik tes tertulis. Teknik ini digunakan dalam pembelajaran living values yang mencakup nilai penghargaan dalam keberagaman, persatuan, dan kedamaian.

Teknik yang digunakan dalam penilaian perilaku adalah teknik running record. Penggunaan running record bersifat fleksibel, disesuaikan dengan kebutuhan dan situasi siswa. Jika perilaku siswa menyimpang dari nilai-nilai moral maka edukator akan mencatat perilaku tersebut dalam running record. Jika perilaku siswa selama belajar tidak menyimpang, maka student record tidak digunakan.

\section{Pendidikan Nilai Nasionalisme dalam Pembelajaran Living Values Menurut Thomas Lickona}

Proses pendidikan nilai nasionalisme dalam pembelajaran living values mencakup tiga unsur penanaman nilai moral menurut Lickona yaitu pengetahuan moral (moral knowing), perasaan moral (moral feeling), dan tindakan moral (moral action).

Penanaman pengetahuan moral bagi siswa prep pada tahap kesadaran dan pengetahuan tentang nilai. Hal ini ditunjukkan dengan peran guru dalam membelajarkan siswa tentang konsep nilai-nilai moral dengan beberapa metode sehingga konsep tersebut mudah dipahami. Penggunaan metode-metode belajar dalam penanaman pengetahuan moral menekankan pada konsep active leraning yaitu pembelajaran berpusat inquiry. Metode-metode yang digunakan yaitu metode cerita, penugasan, role play, dan nonton film. Metode-metode tersebut berperan menguatkan konsep dan pemahaman siswa tentang nilai-nilai penghargaan dalam keberagaman, persatuan, dan kedamaian. Metode pembelajaran juga mendorong siswa aktif memperoleh pengetahuan sehingga mereka mampu membedakan baik-buruk, sayang-tidak sayang, dan suka-tidak suka.

Penanaman pengetahuan moral menjadi tahap penting bagi siswa untuk lebih memaknai konsep nilai dan mengaplikasikan nilai-nilai dalam berbagai situasi. Dengan demikian penanaman pengetahuan perlu dilakukan 
secara terus menerus dan perlu ditingkatkan lagi pada tahap berikutnya (siswa paham kenapa melakukan perbuatan bermoral, memiliki kemampuan mengambil keputusan, dan memahami diri-sendiri). Terbentuknya karakter siswa yang baik maka penanaman moral tidak lepas dari peran guru dalam menanamkan perasaan moral sehingga nilainilai yang dipelajari tidak sekedar dikuasai dan diingat namun dirasakan dalam kehidupannya. Penanaman moral dilakukan secara bersamaan dengan penanaman perasaan moral.

Penanaman nilai dalam pembelajaran living values juga menekankan unsur perasaan moral. Penanaman perasaan moral siswa prep tampak pada tahap kata hati, harga diri dan empati. Hal ini ditunjukkan dengan peran guru dalam membelajarkan konsep nilai menghargai, persatuan, dan kedamaian melalui beberapa metode tertentu yang melibatkan perasaan mereka. Pada tahap harga diri, siswa prep memperoleh fasilitas untuk mengembangkan kemampuan dalam berbuat baik seperti menghargai, menjaga kerukunan, hidup damai serta kemampuan positif atas dasar nilai-nilai yang lain seperti kejujuran, mandiri, konsentrasi, ketelitian, kerjasama, dan tanggung jawab. Pada tahap empati, siswa belajar langsung dari siswa prep yang termasuk kelompok anak berkebutuhan khusus dengan cara belajar dan bermain bersama di lingkungan sekolah sehingga mereka belajar merasakan kondisi yang di alami teman-teman berkebutuhan khusus.

Penanaman nilai yang terakhir adalah tindakan moral. Penanaman nilai dari segi tindakan moral berlangsung di dalam dan luar pembelajaran living values. Dalam pembelajaran living values, siswa dilatih mengembangkan perilaku yang positif melalui teknik tugas kelompok yaitu siswa belajar menemukan konsep pengetahuan nilai moral secara mandiri. Teknik tersebut tidak sekadar mengembangkan pengetahuan nilai moral tetapi juga mengembangkan tindakan moral secara langsung. Teknik tersebut dilakukan dengan sistem peerteaching yaitu siswa berkebutuhan khusus digabung dengan siswa normal untuk mengerjakan tugas bersama. Kegiatan ini menunjukkan interaksi antar siswa cukup positif. Interaksi antar siswa ditunjukkan dengan perilaku saling membantu dan kerjasama dalam menyelesaikan tugas tanpa melihat perbedaan baik agama, ras, dan kebutuhan.

\section{KESIMPULAN}

Berdasarkan hasil penelitian dan pembahasan yang telah disampaikan sebelumnya dapat disimpulkan bahwa:

1. Pelaksanaan pendidikan nilai nasionalisme dalam pembelajaran living values pada kelas prep di SD Tumbuh I Yogyakarta mencakup tiga tahap yaitu perencanaan, pelaksanaan, dan evaluasi pembelajaran.

2. Perencanaan pembelajaran living values berdasarkan pada rambu-rambu kurikulum EYCG (Earlier Years Curicullum guidence) dan dimodifikasi dengan beberapa sumber referensi. Perencanaan pembelajaran mencakup penyusunan silabus dan gambaran program.

3. Pelaksanaan pendidikan nilai nasionalisme dalam pembelajaran living values menekankan pada nilai penghargaan dalam keberagaman, persatuan, dan kedamaian dengan tiga unsur penanaman nilai moral yaitu pengetahuan, perasaan, dan tindakan moral.

4. Evaluasi dalam pembelajaran living values meliputi penilaian hasil belajar dan proses pembelajaran. Penilaian hasil belajar sudah menjangkau ranah pemahaman dan perilaku moral. Penilaian proses pembelajaran dilaksanakan secara lisan tetapi jarang dilakukan secara langsung.

\section{DAFTAR PUSTAKA}

Abi Sarwanto, 2017. Perang Spanduk SARA Jelang Pemungutan Suara. http://www.cnnindonesia.com/ kursipanasdki1/20170406081402-516 -205324/perang-spanduk-sara- jelangpemungutan-suara/. Di akses tanggal 5 April 2017

Ajat Sudrajat, 2011. Membangun Budaya Sekolah Berbasis Karakter Terpuji.

LITERASI, Volume VIII, No. 12017 | 73 
Pendidikan Karakter dalam Perspektif Teori dan Praktik. UNY Press, Yogyakarta.

Aman, 2011. Model Pembelajaran Sejarah. Ombak, Yogyakarta.

Asri Budiningsih, 2004. Pembelajaran Moral. Rineka Cipta, Jakarta.

Crooks \& Stein, 1991. Psychology science, behavior, and life ed). Holt, Rinehart, and Winston, London.

Diane T \& Pilar Quera C, 1994. Living values activities for children ages 3-7. Gramedia, Jakarta.

Dwi Siswoyo, dkk, 2007. Ilmu Pendidikan. UNY Press, Yogyakarta.

Gina Lestari, 2015. Bhinnekha Tunggal Ika: Khasanah Multikultural Indonesia Di Tengah Kehidupan SARA. Jurnal Pendidikan Pancasila dan Kewarganegaraan, 28 (1), hlm 31

Herminarto Sofyan, 2011. Implementasi Pendidikan Karakter melalui Kegiatan Mahasiswa. Pendidikan Karakter dalam Perspektif Teori dan Praktik. UNY Press, Yogyakarta.

I Wayan Koyan, 2000. Pendidikan Moral: Pendekatan Lintas Budaya. Departemen pendidikan Nasional, Jakarta.

Ki Supriyoko, 2001. Menggugat Nilai-Nilai Nasionalisme, dalam Surat Kabar Harian "SUARA MERDEKA", terbit di Semarang, Edisi 6 Agustus 2001. Journal. amikom.ac.id/index.php/Koma/article/ viewFile/3007/pdf_734.

Linda \& Ricahard. E, 1995. Mengajarkan NilaiNilai Kepada Anak. Gramedia Pustaka Utama, Jakarta.

Matthew B. Miles and A. Michael Huberman, 1992. Analisis Data Kualitatif. Universitas Indonesia, Jakarta.

Mei Amelia R dan Ibnu Hariyanto, 2016. Tawuran Pelajar di Jaktim, satu orang Tewas. https://news.detik.com/ berita/d-3431303/tawuran-pelajar-dijaktim-1-orang-tewas. Di akses tanggal 2 April 2017
Moleong, 2005. Metodologi Penelitian Kualitatif. Remaja Rosdakarya, Bandung. Mulyana, 2004. Mengartikulasikan Pendidikan Nilai. Alfabeta, Bandung.

Novita Eka. 2016. Penanaman Nilai Cinta Tanah Air di SD Negeri Sedayu 1 Muntilan Magelang. Jurnal Pendidikan Guru Sekolah Dasar, 4 (5) : 314-315

Rizka Diputra, 2016. Lima Konflik SARA Paling Mengrikan, Ini Pernah Terjadi di Indonesia. http://news.okezone.com/ $\mathrm{read} / 2016 / 02 / 25 / 340 / 1320731 / 1 \mathrm{ima}-$ konflik-sara-paling-mengerikan-inipernah-terjadi-di-indonesia. Di akses tanggal 8 April 2017

Slamet Soewandi, 2005. Perspektif pembelajaran berbagai Bidang Studi. Universitas Sanata Darma, Yogyakarta.

Smaldino, 2005. Instructional technology and media for learning. Pearson Education, Upper Sadle River.

Suharjana, 2011. Model Pengembangan Karakter melalui Pendidikan Jasmani dan Olahraga. Pendidikan Karakter dalam Perspektif Teori dan Praktik. UNY Press, Yogyakarta.

Suparlan Al Hakim, 2016. Pendidikan Kewarganegaraan dalam Konteks Indonesia. Madani, Malang.

Sunarso, dkk. 2006. Pendidikan Kewarganegaraan Buku Pegangan Mahasiswa Paradigma Baru. UNY Press, Yogyakarta.

Syaiful Sagala, 2008. Metode belajar mengajar. Alfabeta, Bandung.

Wina Sanjaya, 2006. Strategi Pembelajaran: Berorientasi Standar Proses Pendidikan. Kencana, Jakarta.

Zamroni, 2011. Strategi dan Model Implementasi Pendidikan Karakter di Sekolah. Pendidikan Karakter dalam Perspektif Teori dan Praktik. UNY Press, Yogyakarta.

Zubaedi, 2006. Pendidikan Berbasis Masyarakat. Pustaka Pelajar, Jakarta. 